\title{
DETERMINATION OF HEAVY METALS IN CHOAPA RIVER SEDIMENTS USING BCR SEQUENTIAL EXTRACTION PROCEDURE
}

\author{
SYLVIA V. COPAJA ${ }^{1 *}$, XIMENA MOLINA ${ }^{2}$ AND ROXANA TESSADA ${ }^{1}$ \\ ${ }^{1}$ Dept.o de Química, Facultad de Ciencias, Universidad de Chile. Las Palmeras 3425, Ñuñoa. Santiago, Chile. \\ ${ }^{2}$ Centro Nacional del Medio Ambiente (CENMA). Avda. Larrain 9975, La Reina, Santiago, Chile.
}

(Received: July 17, 2013 - Accepted: December 11, 2013)

\begin{abstract}
In recent years Chile has experienced a significant increase in mining activities, which has resulted in an increase in waste generation. The dispersion of these residues in the air, water and soil has led to negative changes in the environment.

This main objective of this study is to identify the influence of the copper mine Los Pelambres (station E2) located in the Choapa River Basin (IV Region Coquimbo). To achieve this goal we performed an analysis of the physical and chemical composition of sediment samples in the summer season taken from the rithron to potamon areas of the watershed. River sediments can provide information and influence the degree of pollution in a given area due to mining discharges. The analysis was based on two types of determinations: total metal content, which provides an assessment of the level of contamination, and studies of different chemicals in which the metal is associated with the sediment.

The results of this study showed that station E2 (Cuncumen River) has a particular behavior in the basin, showing higher content of metallic trace elements; for example, the concentration of $\mathrm{Cu}$ (total fraction) was $4814.1 \mu \mathrm{gg}^{-1}$. In the rest of the stations the metal content was less than in $\mathrm{E} 2$ (total $\mathrm{Cu}$ from $42.4 \mu \mathrm{gg}{ }^{-1}$ in E1 to $136.2 \mu \mathrm{gg}^{-1}$ in E5), therefore it is concluded that there is no direct influence of the mining activity of Los Pelambres station (E2) in the rest of the basin.

BCR sequential extraction of sediments, developed under the auspices of the Community Bureau of Reference, indicated metal mobility. Metal mobility is closely associated with the chemical conditions of the system. In general, metals that could have greatest mobility in the basin are: $\mathrm{Cu}, \mathrm{Cd}, \mathrm{Zn}$ and $\mathrm{Mn}$, found in the soluble acid fraction, together with oxidant (organic matter) and reducing ( $\mathrm{Fe}$ and $\mathrm{Mn}$ oxides) conditions.

The cluster analysis of the total fraction of metal content in sediments indicates that the mine discharge site (E2), has a unique behavior in the basin. Station E2 showed a similarity below $50 \%$, while the rest of the basin showed a similarity above $70 \%$.

Overall the results indicate that the Los Pelambres Mine is not a direct source of heavy metals in the Choapa River Basin, which does not imply that station E2 (Cuncumen River) has no influence on the metal content of sediments. To determine the area of this season, the study area should be narrowed to Cuncumen River (E2) section of the Choapa River Basin, since the physical conditions of the system, hydrographic conditions and climatic do not allow a high rate of discharge and mobility of heavy metals from the mining area with high discharge to the last station (Huentelauquen).
\end{abstract}

Keywords: Heavy metals, sequential extraction (BCR), river sediments, Choapa Basin.

\section{INTRODUCTION}

In recent years Chile has experienced a significant increase in mining activities, which has resulted in an increase in waste generation. The dispersion of these residues in the air, water and soil has led to negative changes in the environment ${ }^{1-3}$.

The largest copper deposits in Chile are located in the Andes foothills or areas, which requires the collection centers to use rivers as water sources for their processes, returning lower quality water to cause them natural, due to the incorporation of chemical waste tailings with various minerals such as arsenic, copper, manganese, iron, lead and zinc ${ }^{1}$ which can cause negative impacts in areas adjacent to the area of mineral extraction and water bodies, soils and vegetation ${ }^{4,5}$.

The importance of the study of heavy metals in water and sediments is due to their high toxicity, high persistence and rapid accumulation by living organisms. More important is the analysis of heavy metals in sediments, because they act as carriers and potential sources of contamination, acting as a reservoir. The relevance of the sediments for studies of environmental quality is given by the adverse effects that may occur in aquatic organisms and the environment. Contaminated sediments are in direct contact with the biota, especially the benthic organisms they provide with habitat and food, leading to toxic effects and allowing the bioaccumulation of contaminant species, determining their potential transfer through food chains and eventually harm to human health ${ }^{1,6,7}$. Heavy metals not only will affect the environmental health of an aquatic system directly, they can also do so indirectly by their ability to release pollutants into the water column, making them available to the organisms living in it.

Chemical reactions and hydrodynamic mechanisms occur through the sediment/water interface, where the major chemical reactions occur that determine the mobility of nutrients and contaminating species ${ }^{3,6-9}$.

In comparison with measurements of total metal concentrations, investigations of metal speciation in sediments are more important in providing sufficient information concerning their bioavailability and toxicity, as these characteristics are often dependent on chemical form or chemical species ${ }^{10-12}$. Numerous methods have been developed to determine these associations; these procedures are usually based on the sequential extraction of solid samples with various reactants under defined experimental conditions. One is the BCR fractionation, developed under the auspices of the Community Bureau of Reference. This constitutes a great advantage, since the available reference material allows quality control of measurements ${ }^{14-16}$. The Choapa River basin belongs to the IV Region of Coquimbo, Chile and is situated in the southern part of the province of Choapa. The area under mining activity is reduced but of great economic importance due to the extraction of copper and gold, although the latter is extracted to a lesser extent ${ }^{13}$, the main copper deposit is the Los Pelambres Mine, which has been in operation since 1999.

In this study we analyzed the environmental impact caused by mining of copper in the aquatic environment of the Choapa River Basin, which can be evaluated through distribution of metallic trace elements in sediments (sequential extraction procedure). Further data treatment was carried out by cluster analysis (CA) in order to describe similarities between stations and to group the sampling points according their pollution content ${ }^{17}$.

\section{EXPERIMENTAL}

\section{Study area and sampling}

Samples were taken in January 2008 in summer, which is a season characterized by low water flow and an increased drought. During this period metal concentrations increase because there is no dilution capacity as in the case of high water flow rate, which is considered a time of environmental risk.

As shown in Figure 1 and 2 sediment samples from Choapa were collected at different points in the basin; selection was based on hydrologic criteria: rithron, very steep areas, therefore of high sediment transport, high-speed current, substrates larger rivers and boxed. And potamon finer, softer and pending sedimentation processes where the substrate is important because the flow rate also tends to be lower oxygen concentration and sandy substrates, which produce sedimentation due to the decrease in slope. 
To determine the distribution of these sites six sampling points were chosen: one station without human intervention (rithron: E1), two in the field of middle rithron to characterize the sediments (E2-E3) and a third in the sector which produces potamon increased sedimentation (E4-E5-E6). Site E2 Choapa from Choapa Basin is influenced by the Los Pelambres Mine.

We sampled sediments in each station in triplicate $(1 \mathrm{~kg}$ each, collected in polyethylene flasks) according to the protocol for sediments ${ }^{18}$, which requires collecting samples with a plastic shovel from the top 10 of the superficial sediment zone. At each sampling site, triplicate samples were collected and mixed to ensure that each site sample was representative. Sediment samples sealed in plastic bags and placed in portable cooler at $4^{\circ} \mathrm{C}$.

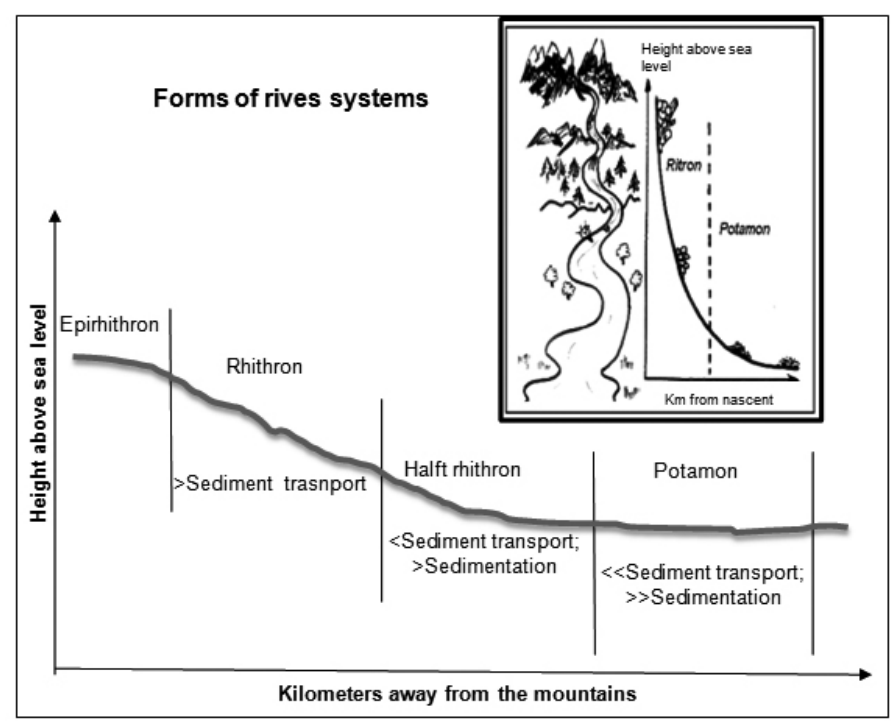

Figure 1. Hydrological criteria to select sampling sites.

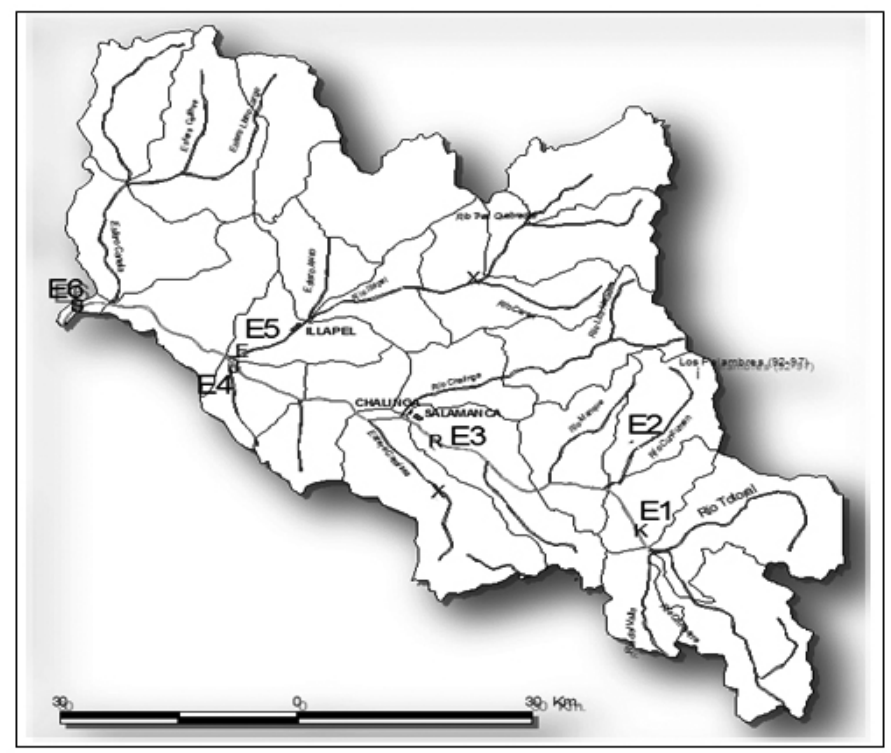

Figure 2. Distribution of sites in Choapa Basin. E1: Cuncumen; E2: Cuncumen River; E3: Salamanca; E4: Black Bridge; E5: Illapel River; E6: Huentelauquen.

\section{Pretreatment of samples}

All samples were transported to laboratory and subsequently stored in a freezer at $-20^{\circ} \mathrm{C}$ upon analysis. Samples were defrosted and dried at temperature below $40^{\circ} \mathrm{C}$ to constant weight. Representative sample for each point by quartering method was obtained and then samples were sieved to collect $<63$ microns grain size fraction which has a strong association with metals ${ }^{19}$.

\section{Characterization of Sediments}

In situ, three type of analysis were carried out on these samples, namely electrical conductivity (EC), $\mathrm{pH}$ and redox potential (Eh) using a portable multiparameter (VWR multi340i).

In the laboratory, Walkley-Black method was used to determine organic carbon content, following the procedure described by Sadzawka ${ }^{20}$ and water soluble phosphorus was determine by the Olsen method $^{20,21}$.

\section{Total metals determination}

For total fraction determination of metals: $\mathrm{Al}, \mathrm{Cd}, \mathrm{Cu}, \mathrm{Cr}, \mathrm{Fe}, \mathrm{Mn}, \mathrm{Mo}, \mathrm{Ni}$, $\mathrm{Pb}$ and $\mathrm{Zn}, 3 \mathrm{~g}$ sediment was digested with a mixture of $7 \mathrm{~mL} \mathrm{HNO}$ (suprapur, Merck) $+21 \mathrm{~mL} \mathrm{HCl}$ (suprapur, Merck), with stirring for $2 \mathrm{~h}$ at $90 \pm 5^{\circ} \mathrm{C}$. Metals were analyzed by ICP-OES (Perkin Elmer Co, Optima-3300XI). All the analyses were compared with reference sediment (river sediment GBW 08301).

\section{Metal fractionation}

The sediments samples were subjected to sequential extraction according to the BCR scheme ${ }^{16,21,22}$, using specific reagents of different extracting power to obtain the following operationally defines four fractions for $\mathrm{Al}, \mathrm{Cu}, \mathrm{Cr}, \mathrm{Fe}$, $\mathrm{Mn}, \mathrm{Ni}, \mathrm{Pb}$ and $\mathrm{Zn}$ in sediments: acetic acid-soluble, exchangeable and bound to carbonates (label fraction) $\left(20 \mathrm{~mL}\right.$ of $0.11 \mathrm{molL}^{-1} \mathrm{HOAc}$ shaking, for $16 \mathrm{~h}$ ), soluble in reducing conditions $\left(20 \mathrm{~mL}\right.$ of $0.50 \mathrm{molL}^{-1} \mathrm{NH}_{2} \mathrm{OHxHCl}$ adjusted to $\mathrm{pH} 2$ with $\mathrm{HNO}_{3}$, shaking for $\left.16 \mathrm{~h}\right)$, soluble in oxidizing conditions $(10 \mathrm{~mL}$ of $30 \% \mathrm{~m} / \mathrm{v} \mathrm{H}_{2} \mathrm{O}_{2}$, digestion and extraction with $25 \mathrm{~mL}$ of $1 \mathrm{molL}^{-1} \mathrm{NH}_{4} \mathrm{OAc}$ $\mathrm{pH} 5$, shaking for $16 \mathrm{~h}$ ), and residual fraction $(10 \mathrm{~mL}$ aqua regia, digestion for $16 \mathrm{~h}$ ). About $1 \mathrm{~g}$ of each sediment was accurately weighed in duplicate in a $50 \mathrm{~mL}$ centrifuge tube. Extract to separate each of the steps $\mathrm{A}, \mathrm{B}$ and $\mathrm{C}$, centrifuged at $3500 \mathrm{rpm}$ for $30 \mathrm{~min}$ (centrifuge model Bocco U-320). The residual fraction $\mathrm{D}$ was treated in a conical flask with Teflon lid on a hot plate to reflux temperature and $90 \pm 5^{\circ} \mathrm{C}$. The supernatant was separated, filtered and finally stored in polyethylene bottles at $4^{\circ} \mathrm{C}$ until analysis by ICP-OES. The residues were washed with $10 \mathrm{~mL}$ distilled water and the washing was discarded. The centrifuge tubes were weighed for volume correction after each $\operatorname{step}^{16,22}$. The concentration of elements was determined by a calibration curve using standards (Titrisol, Merck). Metals were analyzed by ICP-OES (Perkin Elmer Co, Optima-3300XI). The accuracy of the extraction procedure was checked using a certified reference material (river sediment GBW 08301).

\section{Statistical analysis}

In this study the statistical analysis of the results was based on Cluster Analysis $(\mathrm{CA})^{17}$. CA was performed from the original data in order to reduce the variant biases. The Furthest Neighbor method was applied and dissimilarly by City-Block distance.

\section{RESULTS AND DISCUSSION}

\section{Chemical properties of sediments}

Table 1 shows some of the general properties of sediments in the six sites. All samples showed similar $\mathrm{pH}$ values (6.60-7.93), being close to neutral, and in the expected range for most subaqueous marine and non-marine sediments $(6-8)^{23}$. The more acidic $\mathrm{pH}$ corresponded to site E2, which may be due to the presence of acidic properties of metals such as $\mathrm{Fe}$ and $\mathrm{Al}$ due to acid rock drainage (ARD) that occurs in mining sectors. The ARD is based on the surface or subsurface drainage of hydrogen generated by the oxidation of sulfides, including pyrite $\left(\mathrm{FeS}_{2}\right)$ oxidation, among others ${ }^{23}$. The $\mathrm{EC}$ showed high values at station E2, E4 and E6 which would indicate discharge of ions or soluble salts to the sediment. E1 station was the only station having oxidizing conditions due to the high material removal by the effect of slope, the sediment in the other stations was anoxic. Organic carbon content was higher in E5 site realizing the urban contribution highlights. In general degradation of organic carbon may cause a decrease in $\mathrm{pH}$ and Eh reducing release together with oxides of $\mathrm{Fe}$ and $\mathrm{Al}$, freeing some metals adsorbed on these oxides; however, is necessary to consider that some metals can be adsorbed forming chelates ${ }^{15}$. On the other hand, the content of water soluble (available) phosphorus sites include E4 and E5, because urban diffuse pollution inputs. 
Table 1. Properties of six sampling sites of sediments in Choapa Basin.

\begin{tabular}{|c|c|c|c|c|c|}
\hline $\begin{array}{c}\text { Sampling } \\
\text { sites }\end{array}$ & $\begin{array}{c}\mathbf{p H}\left(\mathbf{H}_{\mathbf{2}} \mathbf{O}\right) \\
\mathbf{1 : 2 . 5}\end{array}$ & $\begin{array}{c}\mathbf{C E} \\
\mathbf{( d S / m )}\end{array}$ & $\begin{array}{c}\mathbf{E h} \\
\mathbf{( m v )}\end{array}$ & $\begin{array}{c}\mathbf{\%} \\
\text { Organic } \\
\text { Carbon }\end{array}$ & $\begin{array}{c}\text { Water soluble } \\
\mathbf{P h o s p h o r o u s ~}_{\left(\boldsymbol{\mu g g}^{-1}\right)}\end{array}$ \\
\hline E1 & 7.63 & 0.13 & 113 & 0.41 & 6.5 \\
\hline E2 & 6.60 & 1.47 & -251 & 2.20 & 18.4 \\
\hline E3 & 7.47 & 1.96 & -189 & 1.28 & 18,4 \\
\hline E4 & 7.53 & 1.99 & -80 & 2.20 & 34.8 \\
\hline E5 & 7.47 & 3.15 & -223 & 4.45 & 45.7 \\
\hline E6 & 7.93 & 1.39 & -224 & 2.15 & 18.3 \\
\hline
\end{tabular}

Heavy metals determination: Total fraction

Precision and accuracy of the analytical procedure were controlled by the reference material (river sediment GBW 08301), indicating good agreement between certified and analytical values (recovery over $90 \%$, table 2 ). Replicate measurements of reference material and sediment samples at least $<10 \%$.
Table 2. Comparison of the results of the reference material (river sediment GBW 08301) with certifies data $\left(\mu \mathrm{gg}^{-1}\right)$; the detection limits are indicated $\left(\mu \mathrm{gL}^{-1}\right)$.

\begin{tabular}{|c|c|c|c|c|c|}
\hline Elements & $\begin{array}{c}\text { Certified } \\
\text { value }\end{array}$ & $\begin{array}{c}\text { Measurement } \\
\text { value }\end{array}$ & $\begin{array}{c}\text { Recovery } \\
(\mathbf{\%})\end{array}$ & $\begin{array}{c}\text { Detection } \\
\text { limit } \\
\left(\mathbf{m g L}^{-1}\right)\end{array}$ & $\begin{array}{c}\text { Precision } \\
(\mathbf{\%})\end{array}$ \\
\hline $\mathrm{Cd}$ & 2.45 & 2.33 & 95 & 0.77 & 7 \\
\hline $\mathrm{Zn}$ & 2.51 & 2.26 & 90 & 0.16 & 5 \\
\hline $\mathrm{Cr}$ & 90 & 84 & 93 & 5.43 & 8 \\
\hline $\mathrm{Cu}$ & 53 & 51 & 96 & 3.33 & 7 \\
\hline $\mathrm{Ni}$ & 32 & 30 & 92 & 4.58 & 9 \\
\hline $\mathrm{Mo}$ & 975 & 932 & 96 & 0.15 & 9 \\
\hline $\mathrm{Fe}$ & 39400 & 34096 & 87 & 1.05 & 7 \\
\hline
\end{tabular}

In relation to total fraction of heavy metals, table 3 shows that the higher elemental concentrations were found for $\mathrm{Al}, \mathrm{Fe}$ and $\mathrm{Mn}$ with relatively similar levels throughout the basin, indicating litogenic characteristics ${ }^{24-26}$. E2 mining site was the station that showed the highest values, especially $\mathrm{Cu}$ and $\mathrm{Zn}$. How is speared in sites with mining activities ${ }^{1}$. Those do not seem to be moved along the basin. Mo was under the detection limit in the most of sites. From these data is possible to establish the following order the metals at station E2 as follows: $\mathrm{Fe}>\mathrm{Al}>\mathrm{Cu}>\mathrm{Mn}>\mathrm{Zn}>\mathrm{Cr}>\mathrm{Cd}>\mathrm{Mo}$, remaining relatively similar distribution in the other sites.

Table 3. Heavy metal concentration in sediments, pseudo total fraction, in six sampling stations, of Choapa River Basin.

\begin{tabular}{|c|c|c|c|c|c|c|c|c|c|c|}
\hline \multirow{2}{*}{$\begin{array}{c}\text { Sampling } \\
\text { stations }\end{array}$} & \multicolumn{10}{|c|}{ Metal concentration $\left(\boldsymbol{\mu g g}^{-1}\right)$} \\
\cline { 2 - 12 } & $\mathbf{C d}$ & $\mathbf{Z n}$ & $\mathbf{C r}$ & $\mathbf{C u}$ & $\mathbf{N i}$ & $\mathbf{P b}$ & $\mathbf{A l}$ & $\mathbf{M n}$ & $\mathbf{M o}$ & $\mathbf{F e}$ \\
\hline E1 & 0.9 & 53.1 & 80.1 & 42.4 & 48.6 & 8.9 & 6797.5 & 793.3 & $<\mathrm{LD}$ & 21656.6 \\
\hline E2 & 3.2 & 91.0 & 79.1 & 4814.1 & 51.9 & 17.0 & 15649.1 & 1671.6 & $<\mathrm{LD}$ & 34623.3 \\
\hline E3 & 1.3 & 77.1 & 196.2 & 78.1 & 112.6 & 11.6 & 10746.1 & 659.9 & $<\mathrm{LD}$ & 29154.4 \\
\hline E4 & 1.2 & 56.7 & 96.3 & 70.3 & 55.9 & 8.3 & 8977.1 & 765.0 & 6.7 & 27463.4 \\
\hline E5 & 1.0 & 32.8 & 62.9 & 136.2 & 38.0 & 4.5 & 6200.7 & 356.8 & $<\mathrm{LD}$ & 26070.9 \\
\hline E6 & 1.3 & 62.7 & 128.7 & 90.0 & 77.5 & 9.8 & 10317.1 & 470.0 & 10.0 & 29351.0 \\
\hline
\end{tabular}

The correlations performed between stations (considering total metal concentration), via a cluster analysis as shown in Figure 3. Station E2 (Cuncumen River) has more different behavior of others because it is a tributary of Choapa that is the point of discharge of Los Pelambres Mine. The other station important differences is E6 (Huentelauquen) that is in the more low slope and there are the most influence by the antropic pollution dependent of the urban activities.

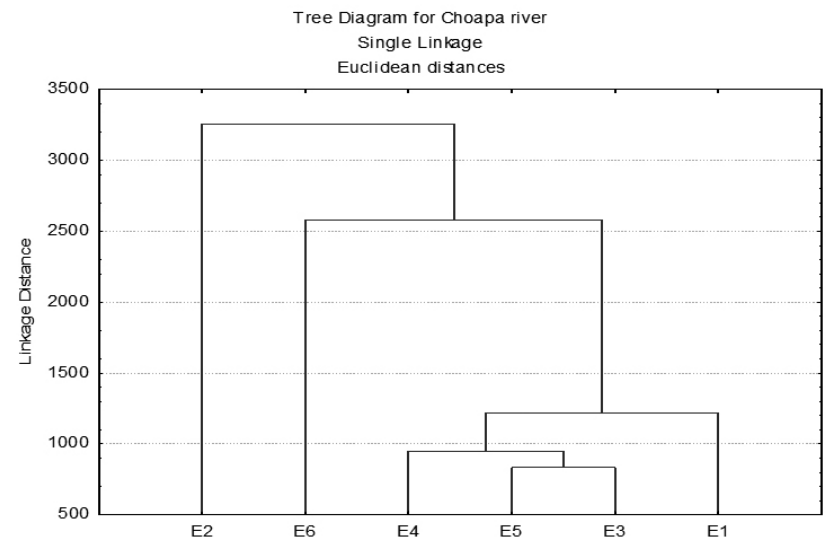

Figure 3. Dendrogram of Choapa River Basin.

\section{Sequential extraction of heavy metal in sediments}

The objective pursued by applying a sequential extraction methodology is to determine as accurately as possible, the distribution of trace elements present in the solid sample, from fractions of different physical-chemical nature. In this distribution is called speciation, and it was found that the elemental distribution determined by applying a method of this type have a direct relationship with the chamber geochemical and bioavailability of the chemical elements in naturals conditions ${ }^{26,27}$
Determining speciation profiles, i.e., the distribution of trace elements between different solid fractions allows a deeper understanding of both the potential bioavailability of these elements and their biological availability 28,29 .

The BCR protocol fractionates the metals into target phases: namely exchangeable and bound to carbonates (A); reducible (bound to $\mathrm{Fe}$ and $\mathrm{Mn}$ oxides) (B), and the oxidizable (bound to organic matter and sulphides) (C). The residues contains the residual metals bound to the minerals and they only soluble in the mixture of strong acids, aqua regia (pseudototal metal), $\mathrm{HNO}_{3}+$ $\mathrm{HClO}_{4}+\mathrm{HF}$ (total metal) (D).

$A$ check on the results of $\mathrm{BCR}$ sequential extraction procedure was performed by comparing the sum of the four fractions $(A+B+C$ and $D)$ with total concentration. The recovery of the sequential extraction was calculated as follows:

$$
\text { Recovery }(\%)=\frac{A+B+C+D}{\text { total concentration of metal }} \times 100
$$

The concentration of the ten metals in the six stations from Choapa basins in each extraction stage of the BCR procedure are shown in table 4 . The results shown in table 4 indicate that the sums of the four fractions are in agreement with the pseudo total metal concentrations with satisfactory recoveries (80.5$117.5 \%)$.

In figure 4 is shows heavy metal $(\mathrm{Al}, \mathrm{Cu}, \mathrm{Cr}, \mathrm{Fe}, \mathrm{Mn}, \mathrm{Ni}, \mathrm{Pb}$ and $\mathrm{Zn})$ fractions in sediments. 


\begin{tabular}{|c|c|c|c|c|c|c|c|c|c|c|}
\hline \multirow{7}{*}{$m$} & $\simeq 9$ & $\stackrel{3}{=}$ & బूे & $\stackrel{+}{+}$ & $\begin{array}{l}\text { I } \\
\infty \\
\infty\end{array}$ & $\stackrel{\overrightarrow{0}}{\Xi}$ & బ் & 广户் & $\stackrel{\stackrel{\mathrm{I}}{\Xi}}{=}$ & ڤू \\
\hline & $\grave{\Delta}$ & $\begin{array}{l}\stackrel{9}{2} \\
\stackrel{+}{0} \\
\end{array}$ & oे & $\stackrel{\infty}{\stackrel{0}{=}}$ & $\underset{\infty}{\infty}$ & $\overline{\mathrm{i}}$ & 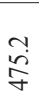 & $\begin{array}{l}0 \\
\dot{I}\end{array}$ & $\stackrel{\bullet}{=}$ & $\vec{r}$ \\
\hline & $\theta$ & $\begin{array}{l}\hat{\alpha} \\
\stackrel{\alpha}{\infty}\end{array}$ & $\overrightarrow{0}$ & $\because$ & $\stackrel{\vec{\lambda}}{\vec{\lambda}}$ & $\underset{\substack{\infty \\
\stackrel{\infty}{\Delta}}}{ }$ & $\ddot{\infty}$ & $\stackrel{\infty}{\infty}$ & $\stackrel{\infty}{\sim}$ & ते \\
\hline & u & $\begin{array}{l}\text { बें } \\
\stackrel{2}{2}\end{array}$ & $\overrightarrow{0}$ & $\stackrel{\circ}{\circ}$ & $\stackrel{\sim}{\infty}$ & ì & ڤें & $\exists$ & $\because$ & $\stackrel{?}{\varrho}$ \\
\hline & $\leadsto$ & $\begin{array}{l}m \\
\infty \\
\vdots \\
n\end{array}$ & $\hat{\delta}$ & $\stackrel{\circ}{-}$ & $\stackrel{?}{?}$ & 䓵 & $\overrightarrow{\mathrm{i}}$ & $\because$ & $\vec{\infty}$ & $\stackrel{\mathrm{I}}{\mathrm{I}}$ \\
\hline & $\varangle$ & $\stackrel{m}{\infty}$ & $\overrightarrow{0}$ & $\vec{\nabla}$ & $\stackrel{\overbrace{}}{\infty}$ & 売 & $\stackrel{\partial}{\otimes}$ & oे & $\stackrel{\circ}{\circ}$ & I \\
\hline & $\simeq 8$ & $\begin{array}{l}0 \\
\dot{\infty} \\
\dot{\infty}\end{array}$ & นู & $\begin{array}{l}\infty \\
\stackrel{\infty}{\infty} \\
\infty\end{array}$ & $\stackrel{n}{0}$ & $\infty$ & ฉू & $\stackrel{\infty}{\stackrel{\infty}{\alpha}}$ & $\tilde{g}$ & \&े \\
\hline \multirow{6}{*}{$\tilde{x}$} & 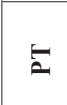 & $\begin{array}{l}\stackrel{a}{a} \\
\stackrel{0}{a}\end{array}$ & $\tilde{o}$ & $\stackrel{\circ}{\ddot{n}}$ & $\begin{array}{l}\stackrel{\text {. }}{\overrightarrow{\mathrm{J}}} \\
\text { Fे }\end{array}$ & 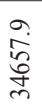 & ర్లి & $\stackrel{\sim}{\infty}$ & $\stackrel{\text { ㅇ. }}{=}$ & $\underset{\dot{q}}{\dot{q}}$ \\
\hline & $\theta$ & 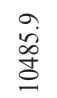 & ฮี & $\stackrel{?}{=}$ & F & $\begin{array}{l}\infty \\
\stackrel{n}{n} \\
\text { an }\end{array}$ & 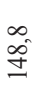 & $\vec{a}$ & $\hat{i}$ & $\overrightarrow{\widetilde{d}}$ \\
\hline & u & $\begin{array}{l}\infty \\
\stackrel{n}{\not} \\
\stackrel{\gamma}{\gamma}\end{array}$ & : & $\exists$ & 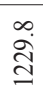 & 守 & $\vec{\circ}$ & $\stackrel{n}{i}$ & $\stackrel{\circ}{-}$ & $\vec{\infty}$ \\
\hline & ص & 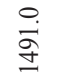 & t: & $n$ & 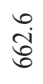 & 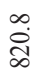 & స్ & $\vec{i}$ & $?$ & $\frac{n}{n}$ \\
\hline & 4 & $\begin{array}{l}\stackrel{\circ}{+} \\
\text { ते }\end{array}$ & $\stackrel{\text { i }}{i}$ & รี & 孚 & $\stackrel{\infty}{\leftrightarrows}$ & $\underset{?}{\stackrel{?}{F}}$ & के & 于 & 离 \\
\hline & $\simeq a^{2}$ & $\vec{\infty}$ & m. & $\frac{m}{\infty}$ & $\begin{array}{l}\infty \\
\stackrel{0}{0} \\
\stackrel{0}{-1}\end{array}$ & 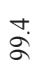 & $\stackrel{\infty}{\infty}$ & స్ & 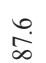 & 范 \\
\hline \multirow{5}{*}{$\vec{\nabla}$} & $\hat{\mathbf{a}}$ & 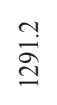 & :n & $\stackrel{+}{\subseteq}$ & 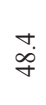 & : & ๙ે & $\vec{n}$ & $a_{\infty}$ & $\overrightarrow{\tilde{n}}$ \\
\hline & $\theta$ & $\underset{\infty}{\stackrel{\vec{\psi}}{\dot{⿰}}}$ & ô. & $\vec{\pi}$ & $\stackrel{\sim}{\simeq}$ & $\overrightarrow{\mathrm{d}}$ & $\stackrel{\overbrace{}}{\Xi}$ & $\stackrel{\circ}{\circ}$ & $\stackrel{\infty}{i}$ & $\stackrel{n}{n}$ \\
\hline & u & $\stackrel{m}{\stackrel{M}{I}}$ & $\overrightarrow{0}$ & $\stackrel{0}{0}$ & $\bar{\Xi}$ & 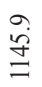 & 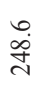 & $\stackrel{ナ}{\unlhd}$ & o. & $\vec{r}$ \\
\hline & $\infty$ & $\begin{array}{l}\dot{\vec{a}} \\
\vec{a}\end{array}$ & $\stackrel{\infty}{\circ}$ & $\stackrel{\circ}{\circ}$ & $\bar{\infty}$ & ن. & 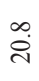 & $\stackrel{\circ}{-}$ & $\because$ & $\infty$ \\
\hline & 4 & $\stackrel{\dot{\infty}}{\circ}$ & ฮั & $\vec{\nabla}$ & $\stackrel{\circ}{\ddot{g}}$ & $\stackrel{\infty}{-}$ & $\begin{array}{l}\text { : } \\
\text { : }\end{array}$ & $\stackrel{\circ}{-}$ & ฮี & $\stackrel{\circ}{\infty}$ \\
\hline \multicolumn{2}{|c|}{ } & $\overline{4}$ & $\Xi$ & ¿ & 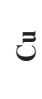 & 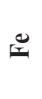 & $\sum_{\Sigma}^{\Sigma}$ & $\ddot{z}$ & 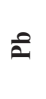 & งี \\
\hline
\end{tabular}

\begin{tabular}{|c|c|c|c|c|c|c|c|c|c|c|}
\hline \multirow{6}{*}{ 㑒 } & $e_{\simeq}^{o}$ & $\stackrel{8}{8}$ & 8 & $\underset{\infty}{\infty}$ & g. & $\stackrel{\text { İ }}{\vec{I}}$ & $\stackrel{?}{3}$ & 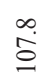 & 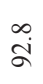 & $\ddot{8}$ \\
\hline & $\underline{\mathbf{2}}$ & 嵩 & $\stackrel{i}{i}$ & $\stackrel{m}{=}$ & $\overline{8}$ & वें & $\begin{array}{l}\text { 迎 } \\
\dot{q}\end{array}$ & 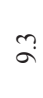 & $\begin{array}{l}\infty \\
\dot{g}\end{array}$ & త్ర \\
\hline & $\theta$ & 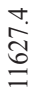 & $\stackrel{?}{-}$ & n. & $\overrightarrow{\mathrm{N}}$ & $\begin{array}{l}\text { ڤे } \\
\text { ठे }\end{array}$ & $\begin{array}{l}\text { तें } \\
\text {. }\end{array}$ & $\stackrel{\sim}{r}$ & $\stackrel{\circ}{\dot{m}}$ & $\underset{\sim}{\infty}$ \\
\hline & u & $\begin{array}{l}\stackrel{0}{\circ} \\
\text { तें }\end{array}$ & $\stackrel{t}{0}$ & $\stackrel{0}{\circ}$ & 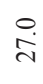 & 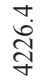 & $\stackrel{\sim}{\sim}$ & $\mathbb{0}_{0}^{+}$ & $\hat{\circ}$ & in \\
\hline & $\infty$ & $\begin{array}{l}\infty \\
\stackrel{\rho}{\varrho} \\
\stackrel{\infty}{\Omega}\end{array}$ & $\overrightarrow{0}$ & $n$ & $\stackrel{\infty}{\oplus}$ & $\begin{array}{l}n \\
\\
\end{array}$ & $\begin{array}{l}\partial \\
\text { oे } \\
\dot{n} \\
\text { dे }\end{array}$ & I & $\vec{\sigma}$ & 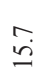 \\
\hline & $\varangle$ & 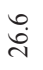 & ฮี & $\overrightarrow{\vec{v}}$ & $\stackrel{\circ}{ \pm}$ & 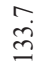 & 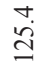 & $\tilde{o}$ & $\stackrel{\circ}{\circ}$ & $\stackrel{m}{2}$ \\
\hline \multirow{6}{*}{ 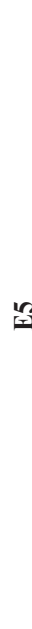 } & $\widehat{a}$ & $\begin{array}{l}\text { na } \\
\stackrel{s}{2}\end{array}$ & $\ddot{~} \ddot{\text { ż }}$ & $\begin{array}{l}\infty \\
\stackrel{0}{0} \\
\end{array}$ & $\overrightarrow{\vec{\infty}}$ & $\begin{array}{l}n \\
0 \\
0 \\
0\end{array}$ & $\begin{array}{l}\stackrel{f}{0} \\
=\end{array}$ & $\stackrel{\vec{g}}{\mathrm{~g}}$ & $\stackrel{m}{g}$ & $\ddot{0}$ \\
\hline & $\hat{\Sigma}$ & 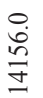 & $\stackrel{\infty}{0}$ & 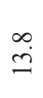 & $\stackrel{\overrightarrow{.}}{\infty}$ & $\begin{array}{l}\text {. } \\
\infty \\
0 \\
0 \\
0\end{array}$ & dे & $\hat{\infty}$ & $\stackrel{n}{*}$ & fे \\
\hline & $\theta$ & 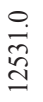 & ชี & $\stackrel{\circ}{\circ}$ & $\stackrel{\sim}{\sim}$ & 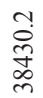 & $\begin{array}{l}\stackrel{0}{\vec{d}} \\
\text { }\end{array}$ & $\stackrel{0}{\infty}$ & $\hat{0}$ & $\ddot{\sim}$ \\
\hline & u & 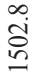 & ?a & $0_{0}^{\circ}$ & ते & 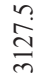 & $\begin{array}{l}\vec{n} \\
\text { in }\end{array}$ & $\stackrel{0}{\circ}$ & $\Xi$ & $\stackrel{i}{i}$ \\
\hline & 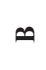 & $\begin{array}{l}\text { na } \\
\vdots \\
\underline{6}\end{array}$ & $\overrightarrow{0}$ & $\stackrel{\circ}{-}$ & 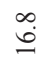 & $\underset{\infty}{\infty}$ & $\stackrel{n}{=}$ & $\tilde{0}$ & $\vec{i}$ & $\dot{ \pm}$ \\
\hline & 4 & 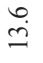 & $\overrightarrow{0}$ & $\overrightarrow{\vec{v}}$ & $\stackrel{n}{n}$ & 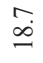 & 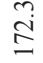 & ชี & $\because$ & $\stackrel{\circ}{\circ}$ \\
\hline \multirow{6}{*}{$\overrightarrow{ \pm}$} & $\stackrel{\overline{0}}{\approx}$ & $\widehat{\check{a}}$ & 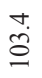 & fy & $\ddot{\infty}$ & $\stackrel{n}{\stackrel{2}{\Xi}}$ & $\vec{\Phi}$ & $\ddot{\Omega}$ & $\begin{array}{l}\infty \\
\infty \\
\infty\end{array}$ & ఖ \\
\hline & $\Sigma$ & $\begin{array}{l}\text { ڤे } \\
\text { ळे }\end{array}$ & $\stackrel{\infty}{0}$ & $\stackrel{\circ}{=}$ & $\underset{\vec{\sim}}{\vec{\sim}}$ & 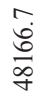 & : & $\stackrel{\circ}{\circ}$ & 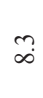 & $\begin{array}{l}\infty \\
\text { గi }\end{array}$ \\
\hline & $\theta$ & 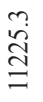 & $\overrightarrow{\vec{v}}$ & $\begin{array}{l}n \\
\infty \\
\infty\end{array}$ & 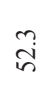 & $\stackrel{\sim}{\vec{n}}$ & $\stackrel{\stackrel{\Perp}{\Xi}}{=}$ & : & $\exists$ & i \\
\hline & u & $\stackrel{d}{\dot{q}}$ & ?a & a & ల & $\stackrel{\vec{m}}{\vec{m}}$ & $\dot{\infty}$ & $\stackrel{\text { - }}{\rightarrow}$ & $n$ & $\infty$ \\
\hline & $\infty$ & 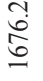 & $\stackrel{m}{0}$ & $\tilde{n}$ & 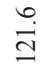 & $\begin{array}{l}\text { 广். } \\
\text { L }\end{array}$ & $\stackrel{\text { ma }}{\stackrel{m}{m}}$ & 9 & $\vec{b}$ & ¿ें \\
\hline & $\varangle$ & $\stackrel{P}{\rightarrow}$ & 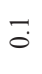 & $\overrightarrow{\vec{v}}$ & $\stackrel{i}{i}$ & $\underset{\dot{g}}{\dot{\theta}}$ & $\overrightarrow{\text { Dे }}$ & $\tilde{o}$ & $n$ & $\stackrel{\sim}{f}$ \\
\hline \multicolumn{2}{|c|}{$\sum_{\bar{z}}^{\bar{\pi}}$} & ₹ & U & J & J & 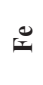 & $\sum$ & $\bar{z}$ & 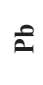 & งี \\
\hline
\end{tabular}



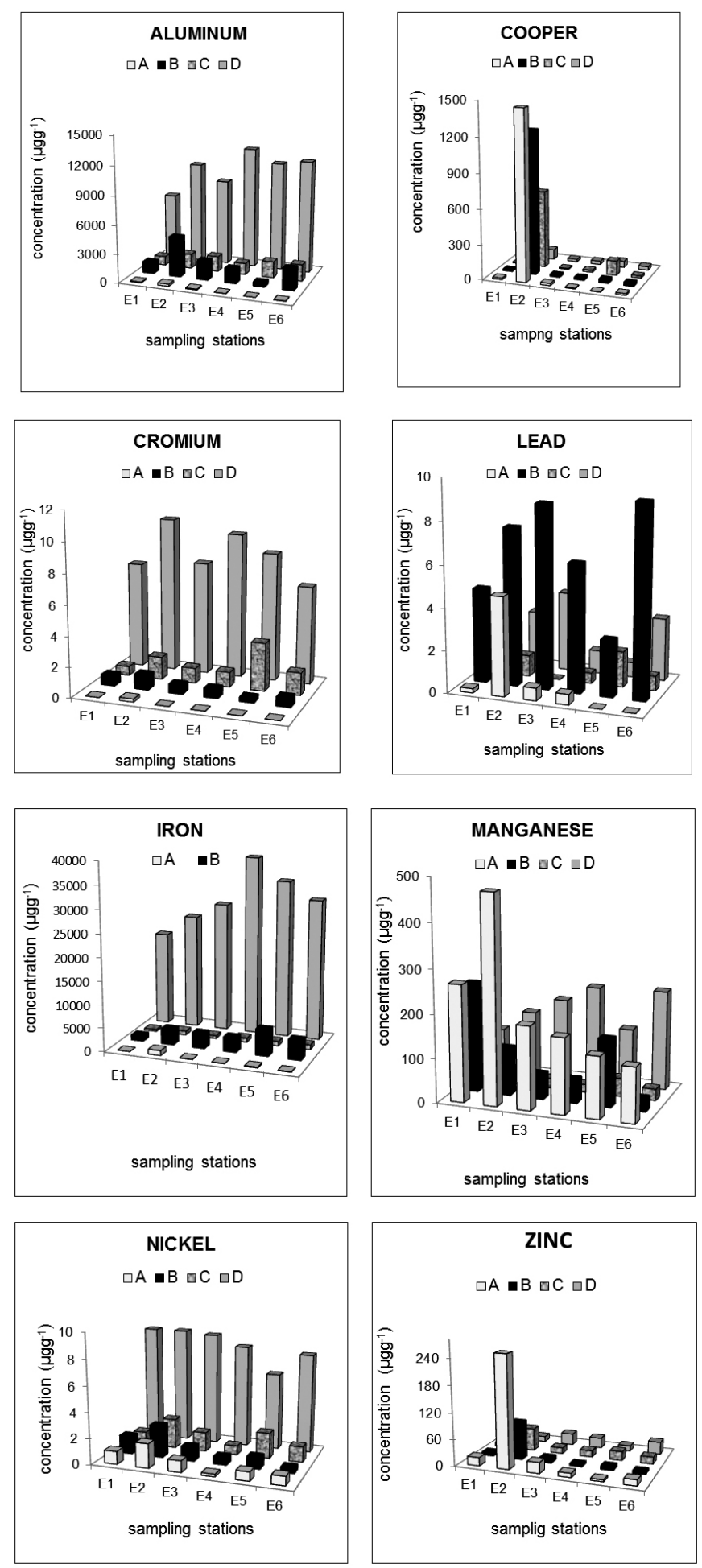

Figure 4. Heavy metal distribution in four different fractions: A: water soluble metals and weak acids; B: metals associated with aluminum and iron oxides; C: metals associated to organic matter; $D$ : residuals metals fraction.

In figure 4 we can observe that the metals: $\mathrm{Al}, \mathrm{Cu}, \mathrm{Cr}, \mathrm{Fe}, \mathrm{Mn}, \mathrm{Ni}, \mathrm{Pb}$ and $\mathrm{Zn}$ were distributed in all the sites and in all the fractions of sediments.

\section{Aluminum, Chromium, Iron and Nickel}

Figure 4 shows that in these elements, the predominant fraction was the reducing fraction (B) and residual one (D), while the water and acid-soluble fraction representing the labile form was the least important (A). Aluminum residual fraction mean was $75.53 \%$ ranged between 84.16 (E4) and 64.11 (E2), while reducing fraction (B) mean was 13.58 ranged 3.26 (E4) and 25.40 (E2). Chromium residual fraction (D) mean was 85.66 ranged between 70.49 (E4) and 87.33 (E5), while reducing fraction (B) average was 8.67 ranged between 0.61 (E1) and 26.70 (E4). Iron residual fraction (D) mean was 79.35 ranged between 79.58 (E6) and 93.66 (E1), while reducing fraction (B) mean was 12.57 ranged between 0.74 (E5) and 13.61 (E5). Nickel residual fraction (D) mean was 70.13 ranged between 84-16 (E6) and 50-47 (E1), while reducing fraction (B) mean was 12.29 ranged between 7.39 (E5) and 20.38 (E4). These results shown that the most non-mobilisable metals were $\mathrm{Al}, \mathrm{Fe}, \mathrm{Cr}$ and $\mathrm{Ni}$ at the residual fraction $\mathrm{D}$, especially for $\mathrm{Al}$ and $\mathrm{Fe}$ showed that these metals are strongly bound to minerals and resistant components of the solid matrix ${ }^{21,1-33}$. This behavior was similar in all the stations.

\section{Copper and Zinc}

$\mathrm{Cu}$ and $\mathrm{Zn}$ concentration is distributed in all the fractions and in all of sites in similar concentration, except in E2 site. In this sampling site soluble fraction $\mathrm{CuA}$ is $42.24 \%$ and fraction for reducing conditions $\mathrm{CuB}$ is $35.37 \%$, in less concentration is $\mathrm{CuC} 19.32 \%$. In the station $\mathrm{E} 4$ oxidant fractions $\mathrm{CuC}$ was important $58.64 \%$. This suggest that copper is mainly bound to organic matter and sulphides, the high stability constant of organic-Cu compounds results in stable complex formation between $\mathrm{Cu}$ and organic carbon ${ }^{36}$. $\mathrm{Zn}$ concentration in E2 sampling site soluble fraction $\mathrm{ZnA}$ and fraction for oxidant conditions $\mathrm{ZnB}$, were important, $60.11 \%$ and $20.12 \%$ respectively. In stations E5 and E6 residual fractions was important, both in similar percentage, 44.49 and $44.75 \%$ respectively. These results show that $\mathrm{Cu}$ and $\mathrm{Zn}$ are accumulate in the site (E2) with mining influence, Los Pelambres Mining, but there is not distribution of metals to the other sites in the Basin.

\section{Lead}

Lead concentration is mainly distributed between the reducing fraction, $\mathrm{PbB}$, in a range between $6.99 \%$ (E5) and $23.58 \%$ (E6). In station $\mathrm{E} 2$ soluble fraction $(\mathrm{PbA})$ was the most important $78.33 \%$, because the mining influence, it is distributed in little concentration in $\mathrm{E} 3(0.6 \%)$ and $\mathrm{E} 4(0.5 \%)$. Pb was distributed along the basins in the oxidizable fraction indicating $\mathrm{Pb}$ is strongly bound to $\mathrm{Fe}$ and $\mathrm{Mn}$ oxides, this is in agree with several studies ${ }^{37,38,}$ which have shown that $\mathrm{Fe}$ and $\mathrm{Mn}$ hydrous oxides are important scavengers in all samples. Residual fraction (E3) $26.95 \%$ and $21.28 \%$ (E6). For other fractions percentages are dispersed and lees than $20 \%$.

\section{Manganese}

Manganese concentration is unevenly distributed between the soluble fraction (MnA), in a range between $17.65 \%$ (E1) and $62.31 \%$ (E2), and $6.72 \%$ residual fraction (E1) and $55.76 \%$ (E6). For other fractions percentages are dispersed and lees than $20 \%$, except MnB in E1,30.18\%. The high percentage of $\mathrm{Mn}$ in weakly-bound fractions was probably due to its special affinity to carbonate, indicating the considerable amounts of Mn may be released into water following non-exchange process and dissociation of Mn-carbonate phase if basins conditions became more $\operatorname{acid}^{39}$.

\section{CONCLUSIONS}

In the sediment of Choapa River were found mainly $\mathrm{Al}, \mathrm{Fe}, \mathrm{Mn}, \mathrm{Cu}$ and $\mathrm{Zn}$, indicating that the basin has a natural and mining influence, depending on the sampling station, highlighting the station E1 (Cuncumen) mainly influenced by litogenic conditions, while E2 station has a mining influence.

$\mathrm{BCR}$ sequential extraction indicates that in general, the metals may be at higher environmental importance are: $\mathrm{Cu}, \mathrm{Mn}$, and $\mathrm{Zn}$ because they can be transfer into the water column, depending on the chemical and physical conditions water system ( $\mathrm{pH}, \mathrm{Eh}, \% \mathrm{OC}$, transfer rate, etc.).

Cluster analysis (CA) shows it is possible that the formation of 3 or 4 groups, where E2 station was different with respect to the other stations.

The low transport capacity of metals since E2 site from the rest of stations could be are due to alkali and reduced sediment conditions which provides slightly soluble species / precipitate species.

\section{ACKNOWLEDGEMENTS}

The authors thank the General Water Direction (DGA) Project Code 300 65693-0. National Environment Centre (CENMA) and Department of Chemistry, Faculty of Science. University of Chile. 


\section{REFERENCES}

1. J. A. Narváez, P. Richter, M. I. Total J. Chil. Chem. Soc. 52, 1261 (2007).

2. S. González. Water, Air and Soil Pollution, 57, 201-208 (1991).

3. D. Zabaski, C. I. Henry, Z. Zhung. and X. Zhang. Water, Air, Soil Pollunt 131, 261 (2001).

4. K. Harmsen "Behavior of heavy metals in soils". Centre for agricultural Publ and Doc. Agric Res. Rep 866 Wageninge. The Netherlands (1997).

5. P. D. Abel "Water Pollution Biology", Taylor and Francis, London, p 180 (2004).

6. A. Kabata-Pendias, H. Pendias. Trace element in Soils and Plants 3erd ed. CRC Press: Boca Raton, FL USA (2001).

7. U. Forstner, W. Solomons. Envirom. Geol. 39, 90 (1999).

8. M. Wardas, L. Budik and H. Rybic. Appl. Geochem. 11, 197 (1996).

9. U. Forstner. Int. J. Environ. An. Ch. 51, 5 (1993).

10. Dirección General de Aguas (DGA), (2004).

11. W. Calamano, J. Hong, U. Fosrtner. Water Science and Technology 28 (8-9) pp 223 (1993).

12. Orkun, I., Davutluoghlu, G. S., Demet, G. K., Turan, Y., G., Cagatayhan, B. F. Desalination 260, 199 (2010).

13. A. Ure, Ph. Quenvauviller, H. Muntau, B. Griepink. Int. J. Environ. Anal. Chem. 51, 135 (1993).

14. C. Gleyzes, S. Tallier, M. Astruc. Trends in Analytical Chemistry 21, 451 (2002)

15. R. A. Sutherland, F. M. G. Tack Anal Chem Acta 454, 249 (2002).

16. I. Ahumada, A. Maricán, M. Retamal, C. Pedraza, L. Ascar, A. Carrasco, P. Richter. J. Braz. Chem. Soc. 21, 721 (2010).

17. Cluster analysis Electronic Text Book StatatSoft "Copyright StatSoft, In. (1984-2004).

18. Simpson A., Graeme E., Batley, Chaslton A., Sharyan J. Handbook for Sediment Quality Assessment (2005).

19. Tam, N. F.Y., Wong, Y.S. Environ. Pollut. 110, 195 (2000).

20. M. A. Sadzawka,. A. Carrasco, R. Grez, M Mora, H. Flores, A. Neaman. Instituto de Investigaciones Agropecuarias (INIA). Serie Actas INIA ${ }^{0}$ 34 (2006).
21. P. L. Blackemore, B. K. Searle, Daly, In Methods for Chemical Analysis of Soils, N. Z. Soil Bureau Scientific Report 80, p 18 (1987).

22. G. Rauret, J. F. López-Sánches, A. Sahunquillo, E. Barahona, M. Lachica, A. M. Ure, C. M. Davinson, A. Gómez, D. Luck, J. Bacon, m. Yli-Halla, H. Muntan, Ph Quenvauviller, J. Envirom. Monit 2, 228 (2000).

23. A. Tessier, P. G. Cambell, M. Bisson. Anal. Chem. 51, 844 (1979).

24. .P. Alvarez-Iglesias, B. Rubio, F. Vilas, Marine pollution Bulletin 46, 491 (2003).

25. J- Oyarzún, H. Maturana, R. Oyarzún. Geometalurgia y Mineralogía. Pp 51 (2009).

26. A. M. Ure, P. H. Quevauviller, H. Muntau, B. Girepink, International J. Environ Analytical Chemistry 51, 135 (1993).

27. A. A. Berner, Petrology 51, 350 (1981).

28. S. V. Copaja, G. Díaz, R. Toro, R. Tessada, P. Miranda and J. R. Morales $J$. of the Chil. Chem. Soc., 57, 1199 (2012).

29. P. López Julian, J- M- Mandado Collado. Estudios Geol. 58, 133 (2002).

30. M. Raksasataya, A. G. Langdon, N. D. Kim, Analyt. Chim. Acta, 332, 1 (1996).

31. H. R. Boluda, V. P. Andreú, I. D. Sanchéz, I. D. Anal Edafol. y Agrobiol. 11-12, 1485 (1988)

32. F. Méndez-Romero, J. Gisber-Blanquer, J. García-Díaz, J., MarquésMatéu, A. Interciencia 28, 1 (2003).

33. N. Breward, M. Williams, D. Bradley. Applied. Geochem.11, 101 (1996).

34. L. Ramos, L. M. Hernandez, M. J. Gonzalez, J. of Environ. Qual. 23, 50 (1994).

35. R. J. G. Mortimer, J. E. Rae., Marine Pollution Bulletin 40, 337 (2000).

36. Morillo, J., Usero, J., Gracia, I., Chemosphere 55, 41 (2004).

37. Zhou, N. Y., Choung, K.Y.N., Chau, K. M., Wong, M. N. Water Res 21, 3331 (1998).

38. Li, X.D., Shen, Z. G., Whai, W.H.G.,Li, ..Z. Mar. Pollut.Buill. 42, 215 (2001).

39. Yongmin, Q., Yang, Y., Jiaguang G., Jiangang Z. Mar. Pollut. Bull. 68, 143 (2913). 